\title{
Buried drip irrigation reduces fungal disease in pistachio orchards
}

\author{
David A. Goldhamer \\ Themis J. Michailides \\ David P. Morgan
}

\section{Alternaria late blight, a fungal disease affecting both leaves and fruit, can lower the quality of pistachios and reduce grower profit. High humidity in orchards increases the magnitude and severity of the blight infections. One cause of high orchard humidity is the evaporation of water from the soil surface, which in turn is enhanced by irrigation systems that} wet the surface. In this study, we tested the use of buried drip irrigation, which reduces orchard floor wetting, to see how well it controlled the disease. When compared with a traditional flood irrigation system, the buried drip system reduced orchard humidity and dew duration and increased temperature. This significantly reduced leaf symptoms of the disease and fruit infection at harvest. Additionally, more shells split open with the buried drip method, resulting in a higher yield of marketable pistachios.

\section{$\triangle$ lternaria late blight (ALB) is 1 difficult to treat in California} pistachio orchards. The pathogen, Alternaria spp., infects both leaves and fruit, causing early defoliation, severe brown-black stains on the shells, and mold contamination of the shells and kernels. In addition, fewer shells split open. The closed shells combined with staining can result in losses of as much as $\$ 1,000$ per acre. Other damage from ALB includes poor flavor and possible mycotoxin contamination.

Generally, Alternaria diseases which affect many agricultural crops including carrot, cotton, tomato, almond, citrus and pear - are difficult

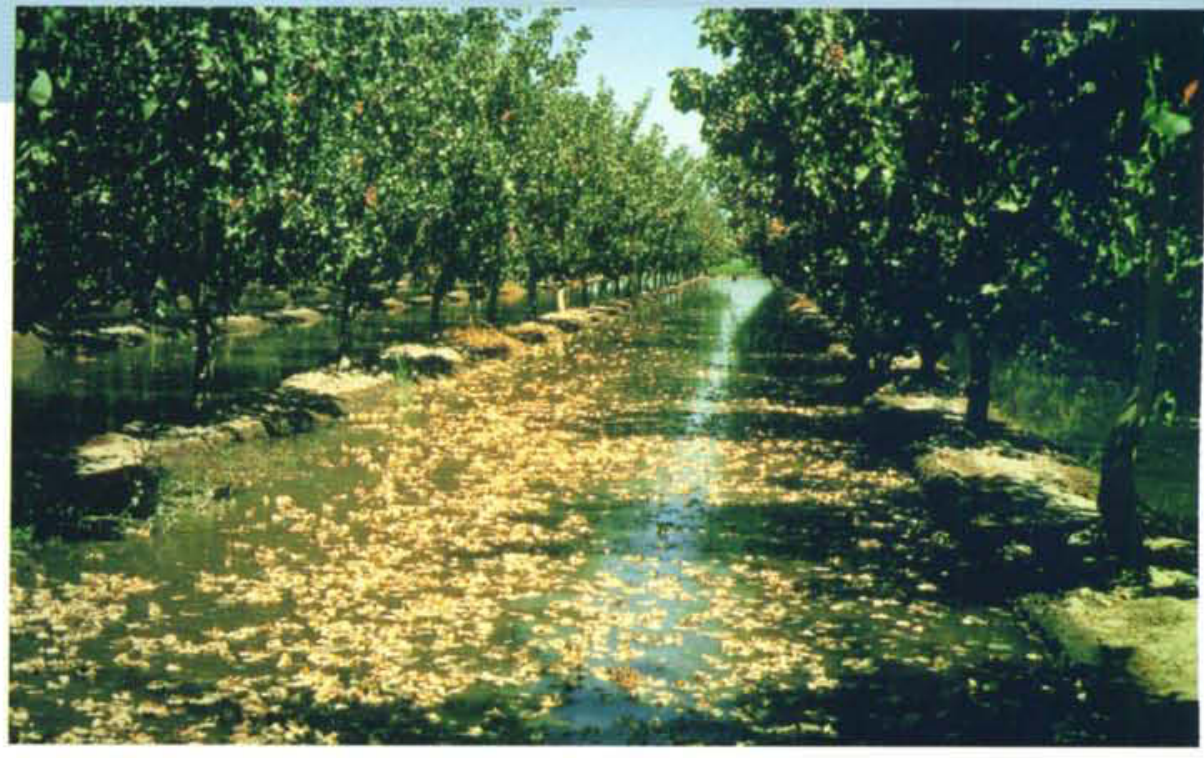

Humidity in pistachio orchards increases the magnitude and severity of Alternaria late blight, a fungal disease that causes defoliation, shell staining, mold contamination and reduced shell-splitting. Flood irrigation, above, can contribute to high humidity in orchards.

to control. Significant control of Alternaria has only been achieved in the last few years with repeated application of azoxystrobin (Abound), which is a member of the new class of strobilurin fungicides. However, repeated fungicide sprays increase costs, can pollute the environment and may lead to pathogen resistance. In addition, the fungicides that are available to pistachio growers are limited and their efficacy is questionable (Michailides and Morgan 1993). Therefore, alternative disease management approaches are needed.

Severe cases of ALB have been identified in irrigated orchards where harvests are delayed and humid days and nights prevail from late August through October. The disease on pistachio leaves and fruit (sold in the shell as in-shell kernels or "nuts") manifests earlier in orchards with flood irrigation than in those with drip/microsprinklers or sprinklers. However, propagule (spore inoculum) populations of Alternaria spp. increase from early August to mid-September regardless of the irrigation system. We define this stage of the season as the critical period for disease development. This period is characterized by increased relative humidity, the onset of dew formation on the leaves and the appearance of the first leaf symptoms of the disease. Control measures should be conducted before this critical period (Michailides et al. 1991).

Orchard humidity depends not only on irrigation frequency but also on the length of time that the soil stays wet. Flood systems, especially when they are used in soils with poor infiltration rates, can result in high humidity for days following irrigation. Although they wet a limited soil area, drip irrigation systems must be operated frequently (every day or two), eliminating the possibility of increasing the irrigation interval. Buried drip irrigation was developed in part to reduce or eliminate surface evaporation (E), one of the two components of orchard evapotranspiration (ETc), and, in turn, save water. Steady improvements in buried drip irrigation technology, including limiting root intrusion and other plugging problems, have made commercial installation feasible. 


\section{Severe ALB in Kings County orchard}

A commercial, flood-irrigated pistachio orchard in Kings County was suffering from severe ALB damage during the mid-1990s. The orchard's heavy soil, coupled with its poor infiltration rate, caused water to stand for 48 to 72 hours and led to a high level of humidity in the orchard. The grower had tried all conventional approaches for reducing the time the soil surface was wetted, including applying gypsum to improve infiltration and converting from flood to microsprinklers in some of his orchards. These measures had not appreciably reduced the incidence of ALB. The grower was spending a great deal of money on an intensive fungicide program for ALB but still experienced severe infections and associated shell staining, particularly when the crop was harvested late. We were asked to participate in a 2-year study to determine if buried drip irrigation could reduce orchard humidity and dew formation, control the disease and im- prove crop productivity without fungicide treatments.

Installing the tubing. One of the problems associated with buried drip irrigation is unintended surface wetting. Sometimes known as "surfacing" or the "chimney effect," it occurs when water moves upward from the emitters through the soil that was disturbed during the tubing installation. This problem defeats the primary benefit of buried drip - a dry soil surface. We conducted preliminary tests in the orchard to determine how deep the tubing would have to be placed to avoid this problem. A depth of 30 inches resulted in the least amount of surface wetting and was chosen as the target depth for installation.

We divided an 80-acre, 12-year-old, flood-irrigated orchard (with 17-footby-19-foot tree spacing) into 12-row plots. A randomized, complete block design was used with five replicates of the flood and buried drip irrigation treatments. We installed buried drip irrigation by shanking in $5 / 8$-inch nominal polyethylene tubing (Drip-In

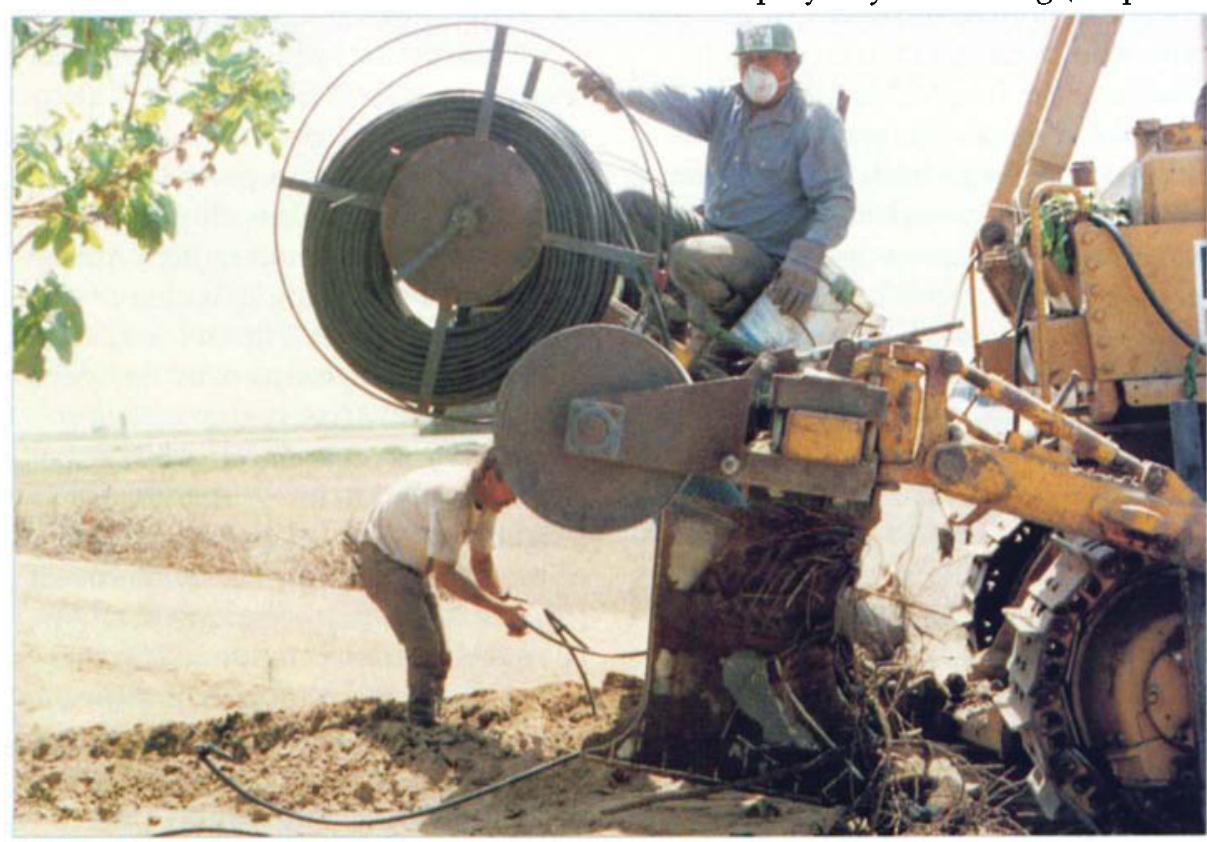

Buried drip irrigation is installed using specialized heavy equipment, above. In this orchard, roots that were inadvertently pruned can be seen at the front of the shank.

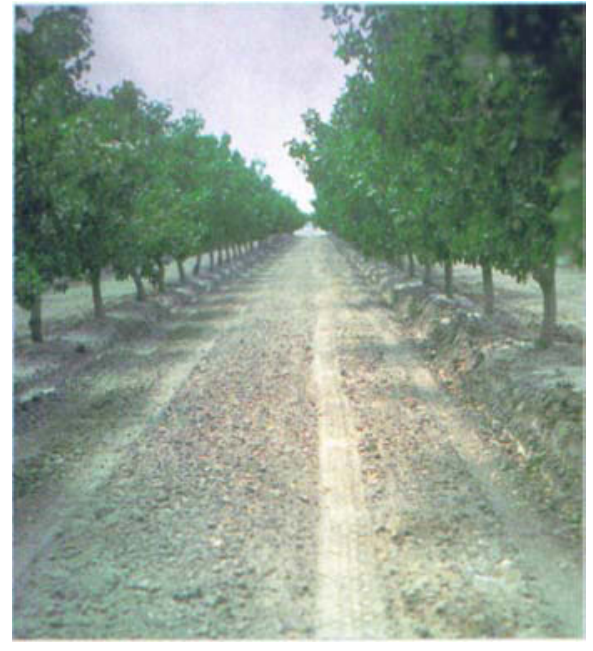

When flood irrigation was compared with buried drip irrigation in a Kings County pistachio orchard, there was a significantly lower incidence of Alternaria late blight with the buried drip system, above, because the orchard floor remained primarily dry.

Irrigation Co., Fresno) with 0.5-gallonper-hour, Treflan-incorporated emitters (Geoflow Inc., Sausalito) placed in the line every 45 inches. The design called for two drip lines per tree row, each spaced 4 feet from the tree row. The largest crawler tractor that would fit in the orchard, a Caterpillar D7, was equipped with two specialized steel shanks and tubing spools mounted on the tool bar. Because of the dense soil, it was necessary to make two passes with the tractor and shanks prior to the pass that installed the tubing. In the initial pass, root pruning was clearly evident as roots with diameters up to 2 inches appeared on the shanks. To reduce root pruning and improve the speed of tubing installation, the lines were moved out an additional foot to extend 5 feet on either side of the tree rows. After we installed the tubing, we flood irrigated the drip rows once to help settle the soil.

Managing irrigation. Applied water amounts generally followed the water budget approach to irrigation scheduling. Reference crop water use (ETo) and published crop coefficients $(\mathrm{Kc})$ were used to determine evapotranspiration. This information was adjusted to account for stored winter rainfall and for the limited surface evaporation with the newly installed 


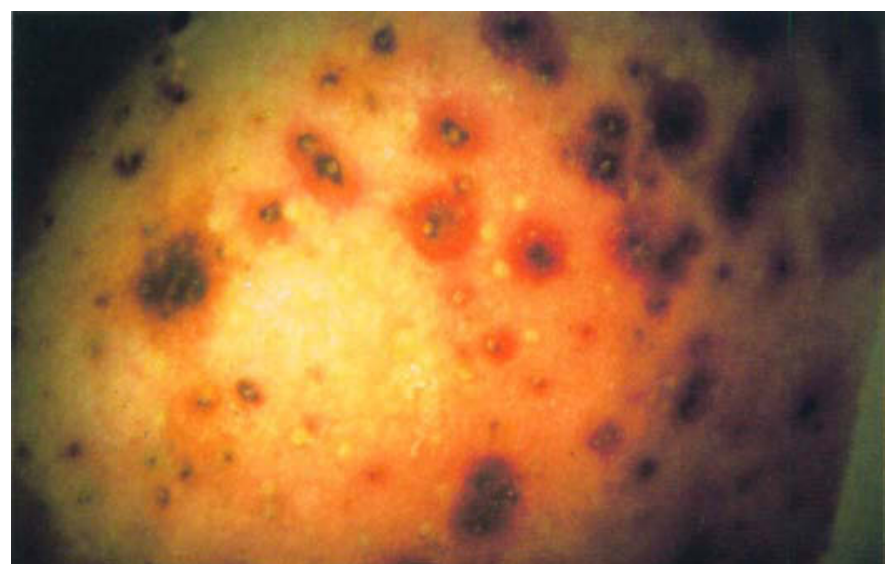

Red halos are characteristic of A/ternaria fruit infections in pistachio.

buried drip system. While the goal was to fully irrigate the trees, the timing in the surface irrigation treatment depended on soil infiltration and other horticultural practices. The cooperating grower made the irrigation decisions. At the peak of the season (July and August), flood irrigation occurred about every 10 days. Drip irrigation. generally took place 3 to 4 times a week. To help reduce the possibility of surface wetting, the drip irrigation was pulsed (1 hour on, 1 hour off) when possible. The total applied water was about 27.5 inches and 29.5 inches per season in the flood and buried drip treatments, respectively. Winter rainfall averaged about 10 inches per season over the 2 years of this study.

Monitoring the disease. We collected fruit and leaves every 2 to 3 weeks from early May to mid-August to determine latent infections of Alternaria spp., using an overnight freezing incubation technique. Fruit and leaves were surface sterilized first in $70 \%$ ethyl alcohol for 10 seconds to 15 seconds and then with $10 \%$ chlorine bleach after adding $0.5 \%$ Tween- 20 surfactant per liter for 4 minutes. We then allowed the fruit and leaves to dry and placed them in plastic containers over waxed wire screens. We held fruit and leaves at $3.2^{\circ} \mathrm{F}$ for 24 hours, then incubated them at $73^{\circ} \mathrm{F}$ after adding water to the containers. Developed colonies of Alternaria spp. were determined after 5 to 7 days of incubation. If we assume that this harsh surface sterilization procedure

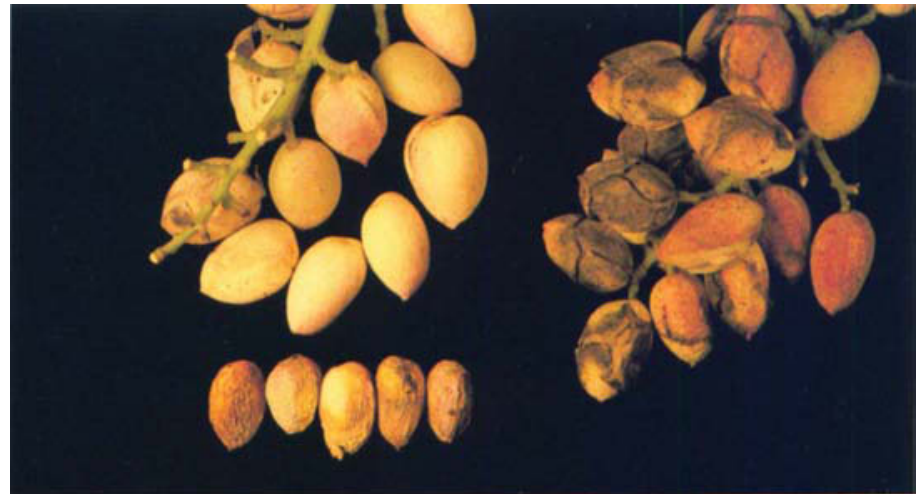

Fruit from the buried drip orchard (left) was healthy, while the flood-irrigated fruit (right) suffered significant fungal damage. Aspergillus blight (bottom row), which occurs in drier orchard environments, was also monitored.

killed all the spores of Alternaria spp. on the surface, freezing should have triggered the growth of latent infections.

The first symptoms of the disease appeared in the orchard just before the middle of August in the first experimental year. We evaluated the incidence of infected leaves three times, on August 16 and August 26, and once at harvest (September 16). For each sampling, we collected 100 leaves per tree from nine trees in the middle rows of each replication, then evaluated them in the laboratory for the number of lesions per leaf (disease severity index). To determine the disease severity index, we classified infected leaves into three categories: (1) those with 1 to 5 lesions, (2) 6 to 10 lesions and (3) 11 or more lesions.

Category $(0)$ represented healthy leaves without Alternaria lesions (table 1).

Because fruit symptoms appear later than leaf symptoms, we evalu- ated the disease on the fruit only at harvest in both years. We collected 30 to 35 fruit clusters from each of nine trees per replicate and used 200 fruit subsamples per tree to evaluate ALB infection.

Since tree stress can affect fruit harvestability, the effectiveness of mechanical tree shaking in removing fruit (harvestability) was determined by individually shaking four trees per replicate and hand harvesting the fruit remaining in the tree. Gross fruit yields were determined by weighing all harvested fruit from the 10 interior rows per replicate. We used commercial analysis to assess nut quality, in terms of shell splitting, shell staining and insect damage.

\section{Microclimate influence}

In late June, single microloggers (electronic data storage devices) were placed in selected tree canopies located in the middle of adjacent repli-

\begin{tabular}{|c|c|c|c|c|c|}
\hline \multirow{3}{*}{ Irrigation regimes } & \multicolumn{5}{|c|}{$\begin{array}{l}\text { ABLE 1. Mean incidence and severity of Alternaria late blight } \\
\text { of pistachio leaves at harvest for two experimental years }\end{array}$} \\
\hline & \multicolumn{3}{|c|}{ Infected leaves (\%) } & \multirow{2}{*}{$\begin{array}{l}\text { Leaf disease } \\
\text { indext }\end{array}$} & \multirow{2}{*}{$\begin{array}{l}\text { Infected leaves } \\
\text { total (\%) }\end{array}$} \\
\hline & $1-5^{\star}$ & $6-10$ & $\geq 11$ & & \\
\hline Flood & $27.9 \mathrm{a} \ddagger$ & $10.7 a$ & $15.9 \mathrm{a}$ & $0.97 a$ & $54.5 \mathrm{a}$ \\
\hline Buried drip & $8.0 \mathrm{~b}$ & $1.5 b$ & $0.8 b$ & $0.14 b$ & $10.3 \mathrm{~b}$ \\
\hline LSD & 2.9 & 2.8 & 3.8 & 0.15 & 5.5 \\
\hline \\
\hline \multicolumn{6}{|c|}{+ Disease index was calculated with the formula: $D I=\frac{A \times 0+B \times 1+C \times 2+D \times 3}{A+B+C+D}$} \\
\hline \multicolumn{6}{|c|}{$\begin{array}{l}\text { in which } A, B, C \text { and } D=\text { the number of leaves in each } 0,1,2 \text { and } 3 \text { disease severity categories, } \\
\text { with } 0,1 \text { to } 5,6 \text { to } 10 \text {, and } 11 \text { or more lesions per leaf, respectively. }\end{array}$} \\
\hline \multicolumn{6}{|c|}{$\begin{array}{l}\text { ₹ Values in each column not followed by the same letter are statistically different at the } 5 \% \\
\text { confidence level using Duncan's new multiple range test. }\end{array}$} \\
\hline
\end{tabular}




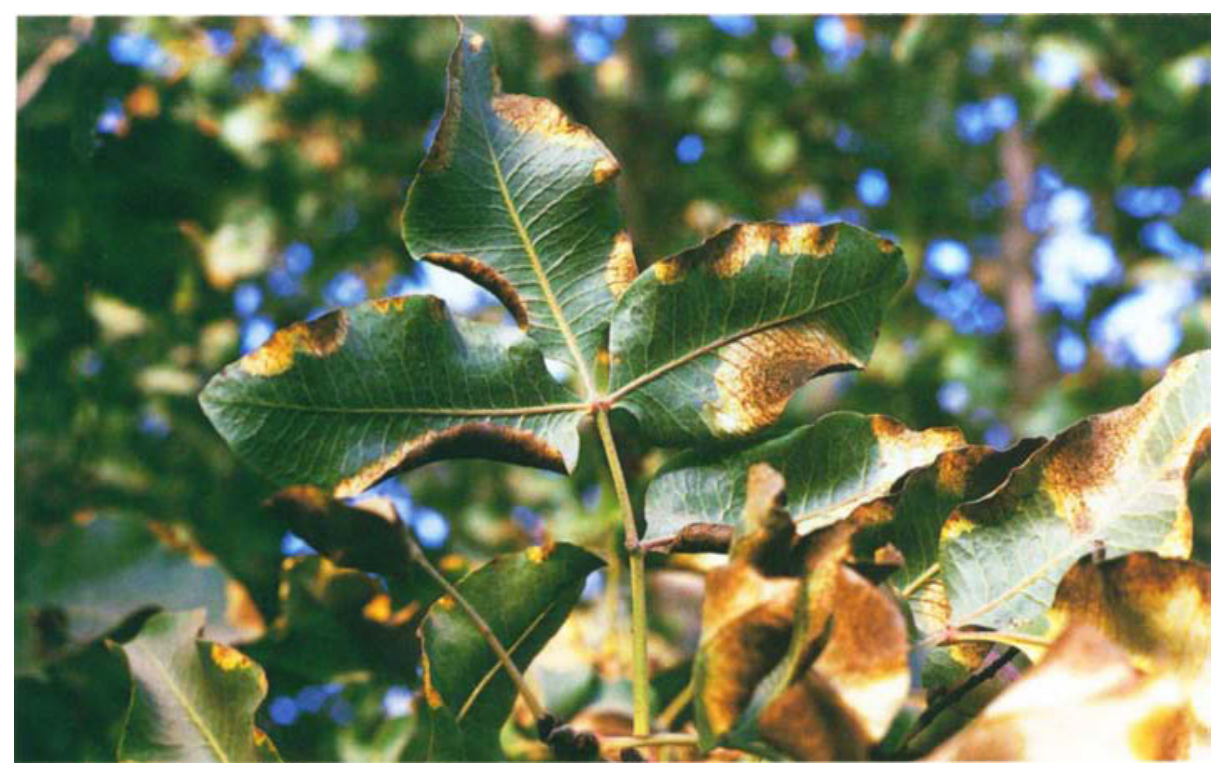

By converting from flood to buried drip irrigation, the orchard microclimate can be significantly altered to improve the yield of marketable fruit, without fungicide sprays. Typical Alternaria late blight symptoms are apparent on pistachio leaves, above.

cates of both the flood and buried drip treatments, to record atmospheric conditions. Although the emitters had been placed deep in the soil (30 inches) and the drip system was pulsed, some surface wetting occurred (between 5\% and $20 \%$ of the orchard floor). Nevertheless, orchard atmospheric conditions were dramatically different for the two irrigation regimes.

Higher maximum air temperatures $\left(2^{\circ} \mathrm{F}\right.$ to $\left.3^{\circ} \mathrm{F}\right)$ were recorded with the buried drip in the season following installation (fig. 1A). Both relative humidity and the number of hours per day with relative humidity above $90 \%$ and above $95 \%$ were significantly lower with the buried drip (figs. 1B1D). Similar climatic differences were recorded in the second experimental year. Dew duration on the leaves in the buried drip was generally much shorter than with the flood, differing by as much as 5 hours (fig. 2). These differences were greater just after the completion of a flood irrigation.

The reduced humidity clearly created a less favorable environment for disease infection and development. Although each replicate was 12 rows wide, there are spikes in the buried drip data that correspond to the flood irrigation dates (figs. 1 and 2). This bleed-over effect from the flood to the drip replicates reduced microclimatic differences between the irrigation treatments. One would expect even larger relative impacts on microclimate in orchards that are fully converted from flood to buried drip irrigation.

\section{Fruit and leaf infection}

The incidence of latent ALB fruit infection ranged from $43 \%$ to $90 \%$ from early May through mid-July in the first experimental year, but there were no significant differences between the irrigation regimes (fig. 3). This suggests that the green fruit was equally susceptible to the establishment of latent infections and that there was equal potential for the disease to develop afterward. However, by mid-August, $93 \%$ of fruit from flooded trees had latent infections compared with $72 \%$ of fruit from buried drip-irrigated trees. Similar results were obtained in the second monitored season. At harvest, ALB infection on fruit was $21 \%$ and $50 \%$ (first year) and $21 \%$ and $37 \%$ (second year) for the buried and flood treat-

Fig. 1. (A) Temperature, (B) mean relative humidity $(\mathrm{RH}),(\mathrm{C})$ hours per day above $90 \%$ RH and (D) hours per day above $95 \%$ RH in adjacent flood and buried drip plots during the season following tubing installation.

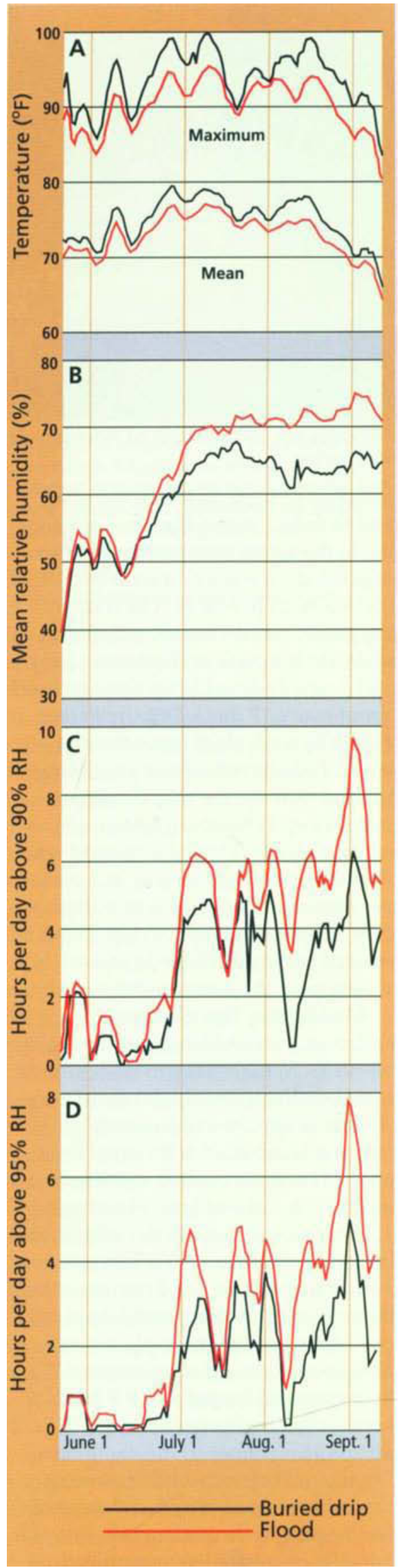




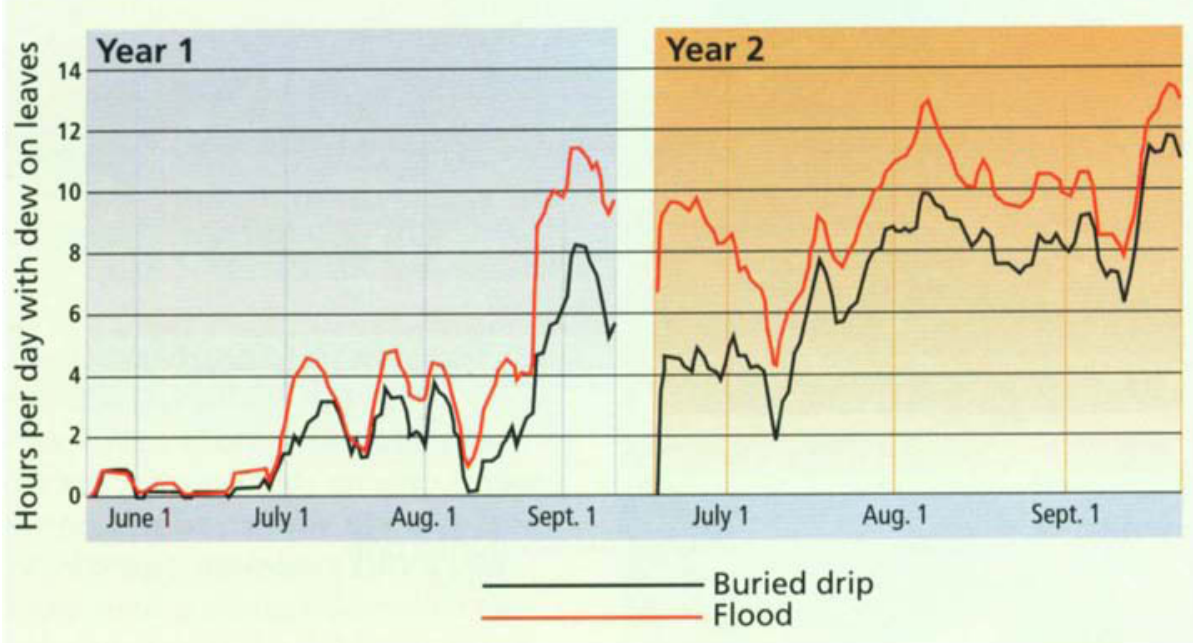

Fig. 2. Hours per day with dew on pistachio leaves in flood and buried drip irrigation regimes.

ments, respectively. These values were significantly different.

The overnight freezing technique also indicated that there were irrigation treatment differences in latent infections of fruit by Aspergillus niger (the pathogen causing Aspergillus blight of pistachio), which can also occur in drier orchard environments. Aspergillus blight can cause a bright yellow staining of the shell that is distinctly different from the brown-black staining caused by Alternaria species. In mid-August, $31 \%$ of the fruit from trees with the buried drip were infected by $A$. niger compared with only $16 \%$ collected from the flood irrigated trees - a statistically significant difference. However, at harvest there were no differences between the treatments, and less than $1 \%$ of the sampled fruit showed Aspergillus blight symptoms.

The first leaf symptoms of ALB appeared during mid-July in the first year and during the last week of July in the second year, and increased more rapidly with time in the flooded trees (fig. 4). At harvest, about $55 \%$ of the leaves in the flooded trees had ALB lesions compared with about $10 \%$ of those in trees irrigated by buried drip. The majority $(77.7 \%)$ of the infected leaves in the buried drip replicates had only 1 to 5 lesions per leaf while $48.8 \%$ of the infected leaves in the flood replicates had six or more lesions per leaf (table 1). Therefore, altering orchard atmospheric conditions (temperature, humidity and leaf wetness duration) decreased the incidence and severity of the disease on leaves by $82 \%$.

\section{Fruit production}

Mean gross yields for the 2 years of this study were somewhat lower (although not statistically so) with the buried drip irrigation (table 2). However, shell splitting was significantly greater with the buried drip; split nuts accounted for $59 \%$ and $70.5 \%$ of the harvested nuts on a dry weight basis for the flood and buried drip irrigation, respectively. We speculate that the disease-related leaf necrosis in the flooded trees reduced photosynthesis and, in turn, the sugars necessary for growth of the specialized cells that occur along the suture line of the shells and cause splitting. The improved shell splitting with the buried drip resulted in a significant increase in marketable product (table 2). We believe that the production differences between flood and buried drip irrigation would likely have been greater if the different systems could have been better isolated, as they would be if the entire orchard were converted to buried drip.

We anticipated that the primary

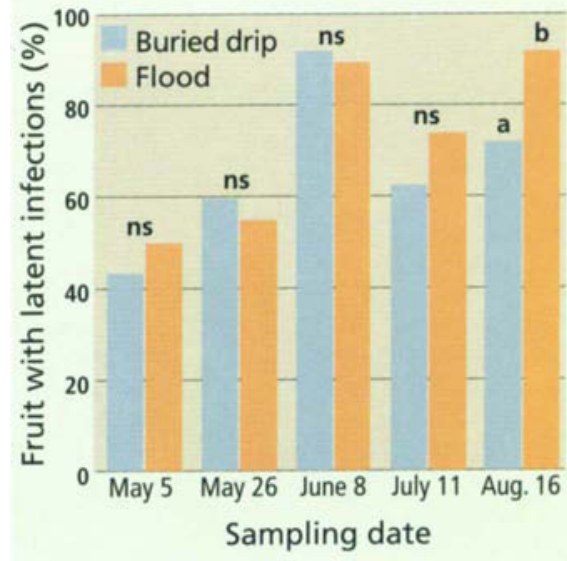

Fig. 3. Latent infection of pistachio fruit by Alternaria species determined by using overnight freezing incubation technique on samples collected periodically during first experimental year. benefit of reduced disease pressure would be less shell staining rather than improved shell splitting. Instead, shell staining was low and there was no significant difference between the treatments (table 2). We believe that the relatively low level of stain was due to the early harvest. Our growercooperator had learned by experience that he could avoid serious ALB degradation in this orchard by harvesting early. Early harvest (about 1 week to 2 weeks before normal harvest) of orchards with ALB can significantly reduce shell staining because Alternaria lesions on fruit do not have enough time to develop and decay the hulls. Our previous work showed that shell discoloration was related to fungal decay (Doster and Michailides 1999).

Delaying harvests by 10 to 20 days significantly increased the number of nuts with excessive shell stain (greater than $10 \%$ of the outer surface of the shell discolored)(Doster and Michailides 1997). The downside of harvesting early is that shell splitting can be reduced. Insect damage varied little between irrigation treatments (table 2).

\section{Sustainability of buried drip}

While gross production was not affected by the different irrigation systems, we noted that the tree canopies 


\begin{tabular}{l} 
FABLE 2. Mean crop production parameters \\
for the two experimental years \\
\hline \hline \multicolumn{3}{c}{ Flood } & Buried drip \\
\hline
\end{tabular}

with buried drip were smaller than the flooded trees at the end of the season following installation of the tubing. We suspect that this was due to the severe root pruning that occurred during the installation; carbon assimilate that would normally have been available for canopy development was used by the increased root growth. We were concerned that production would be reduced in the following season(s) because fruit load can depend on the amount of fruit wood carryover from year to year. This fear was not borne out; there were no reductions in relative gross fruit yields in the buried drip trees for the two seasons following installation. Visual inspection showed that the tree canopy size differences evident in the season immediately following the installation of the buried drip lines had vanished by the second season.

Another concern with buried drip irrigation is emitter clogging. The grower-cooperator reports that after 6 years of operation, there has been no measurable décrease in the system operating flow rate. This suggests that root intrusion and clogging from particulate or organic material have been minimal. The grower-cooperator has visually inspected the emitters by digging pits and has verified that root in-

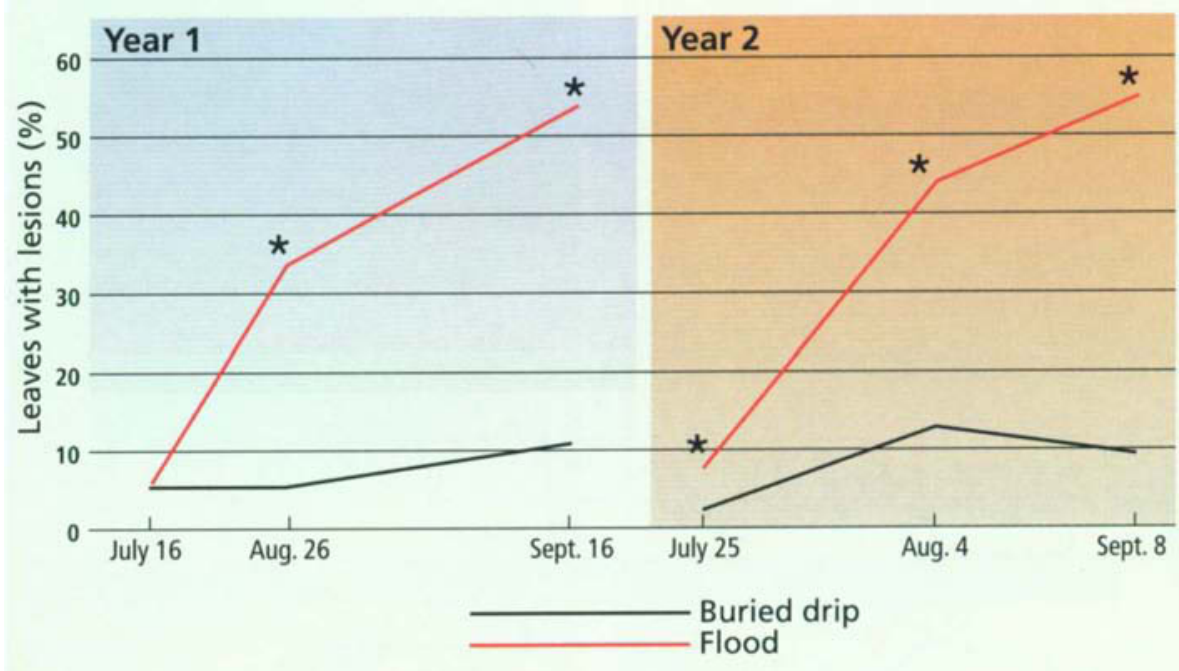

Fig. 4. Changes in percentage of pistachio leaves infected with Alternaria late blight over time. Asterisks indicate statistically significant difference between flood and buried drip irrigation regimes. (The last dates of recording the disease also indicate dates of commercial harvest.)

trusion is negligible. Growers must carefully monitor buried drip system performance, including flow rates, to ensure that they can identify the onset of any emitter clogging and take action.

We have shown that converting from flood to buried drip irrigation can alter orchard microclimate. In an orchard afflicted with a serious ALB problem, these changes can significantly improve the yield of marketable product. This approach to disease management is attractive in that it potentially saves water and reduces the need for fungicide sprays. Using buried drip irrigation to control fungal diseases may also be possible in other orchard crops where irrigation-related high humidity has been identified as the primary factor contributing to the disease (Teviotdale et al. 2001).

\section{D.A. Goldhamer is Cooperative Extension} Water Management Specialist, Department of Land, Air and Water Resources, T.J. Michailides is Professor, and D.P. Morgan is Staff Research Associate, Department of Plant Pathology, UC Davis, located at the Kearney Agricultural Center, Parlier. The authors gratefully acknowledge the assistance of the cooper- ators, Nichols Pistachio, especially Chuck Nichols and John Starling; and Scott Britten of Bennett and Bennett Irrigation, who designed the buried drip system. They also express appreciation to Mario Salinas, Chuy Salinas, Miguel Marquez, Lorene Boeckler, Kevin Tsuda, Vincent Bajman, Adam Sullivan, Martin Ruepp, Adrian Ziliani and Nancy Flory for their help in field monitoring and sampling. The California Pistachio Commission provided partial funding for this work.

\section{References}

Doster MA, Michailides TJ. 1997. The effect of delaying harvest on pistachio nut quality. California Pistachio Industry Annual Rep Crop Year 1996-97. Fresno, CA. p 82-4.

Doster MA, Michailides TJ, 1999. Relationship between shell discoloration of pistachio nuts and incidence of fungal decay and insect infestation. Plant Dis 83:259-64.

Michailides TJ, Morgan DP. 1993. Principles for the control of Alternaria late blight of pistachio caused by Alternaria alternata in California. Proc Ninth GREMPA Meeting-Pistachio, Bronte-Sciacca, Italy, May 20-21, 1993. p 56-63.

Michailides TJ, Morgan DP, Wang $J$. 1991. Control of Alternaria late blight of pistachio by manipulation of irrigation. Phytopathol 81:1163.

Teviotdale BL, Goldhamer DA, Viveros M. 2001. Effects of deficit irrigation on hull rot disease of almond trees caused by Monilinia fructicola and Rhizopus stolonifer. Plant Dis 85:399-403. 